\title{
Tratamiento de anquilosis tempomandibular en la infancia mediante artroplastia y distracción de tejidos blandos
}

\author{
Management of temporomandibular ankylosis during childhood \\ by means of arthroplasty and soft tissue distraction
}

\author{
M.A. Morey Mas', J. Caubet Biayna', J.I. Iriarte Ortabe', P. Quirós Alvarez², A. Pozo Porta², \\ I. Forteza-Rey
}

Resumen: Los traumatismos que afectan a los cóndilos mandibulares pueden ocasionar una anquilosis de la articulación temporomandibular que, si se produce en edad de crecimiento, puede dar lugar a una deformidad facial con asimetría o retrognatia. Entre los diferentes tratamientos utilizados, la distracción osteogénica ofrece unas ventajas, entre ellas la posibilidad de aplicación en la infancia y la elongación de tejidos blandos. Presentamos un caso de anquilosis temporomandibular bilateral en una niña de 9 años, que tratamos con distracción extraoral tras resección del bloque anquilótico, pero sólo con la finalidad de elongar los tejidos blandos y mantener el espacio en la nueva cavidad glenoidea para evitar la reanquilosis y favorecer la remodelación del cóndilo.

Palabras clave: Articulación temporomandibular; Anquilosis; Distracción; Infancia.

\section{Introducción}

La alteración ocasionada en los cóndilos mandibulares durante la infancia puede provocar anquilosis y alteración del crecimiento mandibular. Las causas más frecuentes de daño condilar son los traumatismos y las infecciones, entre otras. ${ }^{1}$

Cuanto más temprana sea la edad de presentación del trastorno condilar y más se retrase la instauración del tratamiento, mayor podrá ser el grado de deformidad facial. Esta deformidad será diferente si la alteración condílea es uni o bilateral. En el primer caso se produce limitación de la apertura oral y una asimetría facial consecuente

\footnotetext{
1 Médico Adjunto. Servicio de Cirugía Oral y Maxilofacial

2 Médico Residente. Servicio de Cirugía Oral y Maxilofacial

3 Jefe de Servicio. Servicio de Cirugía Oral y Maxilofacial

Hospital Universitario Son Dureta, Palma de Mallorca
}

\section{Correspondencia:}

Miguel Angel Morey Mas

C/ Alexandro (pintor), $\mathrm{n}^{\circ} 6$

07141 Marratxí (Baleares)

Email: mmorey@arrakis.es
Abstract: Condylar damage can produce temporomandibular joint ankylosis. If ankylosis ocurrs in early childhood can develope facial asymmetry or mandibular hypoplasia. In these cases, several therapeutic options have been used, but distraction osteogenesis offers a new excellent alternative because it allows elongation of soft tissues and can be performed in childhood.

We present a bilateral temporomadibular joint ankylosis in a 9 years old girl, who was treated by means an arthroplasty and extraoral distraction devices, only for elongation of soft tissues and keeping space between skull base and mandibula to avoid reankylosis and to allow condylar remodelation.

Keywords: Temporomandibular joint; Ankylosis; Distraction; childhood.

\section{Introduction}

The changes that take place in the mandibular condyles during childhood can cause ankylosis and an alteration in the growth of the mandible. The most frequent causes of condylar damage are, among others, traumatic injury and infection. ${ }^{1}$

The younger the patient with a condylar disorder, and the longer the delay in commencing treatment, greater will be the degree of facial deformity. This deformity will be different depending on if the condyle alteration is uni- or bilateral. Firstly, there will be limited oral opening and facial asymmetry consistent with mandibular hypoplasia of the affected side; the chin is retruding and deviated towards the affected side; the ipsilateral gonion angle is higher; on the occlusal plane there is an inclination of the lower incisors towards the healthy side, there is a cross bite on the affected side, and an inclination of the occlusal plane (canting). In the case of bilateral ankylosis, the posterior facial height is shortened, retrognathia appears and there is limited oral opening, 
a una hipoplasia mandibular del lado afecto; el mentón está retruído y desviado hacia el lado afecto; el ángulo goníaco ipsilateral está más alto; oclusalmente se produce una inclinación de los incisivos inferiores hacia el lado sano, mordida cruzada en el lado afecto e inclinación del plano oclusal (canting). En el caso de una anquilosis bilateral, disminuye la altura facial posterior, aparece retrognatia y limitación de la apertura oral, con cierto grado de acortamiento e hipertrofia de los músculos maseteros, pterigoideos, temporales y suprahiodeos, debido a contracciones isométricas. ${ }^{2}$

Hasta la fecha, el tratamiento más conocido de la anquilosis de la ATM consiste en resecar el bloque anquilótico y fijar un injerto costocondral con la finalidad de restaurar la altura facial, simetrizar la deformidad y recuperar la apertura oral. Sin embargo, el potencial de crecimiento de este injerto es impredecible, necesita realizarse un bloqueo intermaxilar y no está exento de complicaciones en la zona donante. ${ }^{3}$

En los últimos 15 años la distracción osteogénica a nivel mandibular ha supuesto una gran aportación en el tratamiento de estos pacientes, especialmente en niños.4 Técnicamente, se realiza una resección del bloque anquilótico y una osteotomía en la rama vertical afecta; una vez comprobado el vector de distracción, se coloca el distractor y se inicia la elongación tras un período de latencia. De este modo, se consigue restaurar la simetría mandibular, corregir la oclusión y se logra una correcta apertura bucal.5-6-7-8

En el caso que presentamos hemos utilizado la técnica de distracción con la finalidad de elongar los tejidos blandos y mantener el espacio entre la cavidad glenoidea y el cuello del cóndilo resecado para evitar el colapso y reanquilosis y, de este modo, estimular la formación de un neocóndilo.

\section{Caso clínico}

Presentamos el caso de una niña de 9 años procedente de un país africano que fue remitida a nuestro Servicio a través de una ONG. Presentaba una limitación de la apertura oral de $5 \mathrm{~mm}$ a consecuencia de una caída casual hacía 7 años con fractura bicondílea. A la exploración se observaba una hipoplasia mandibular sin asimetría, oclusión en clase II con compensación de incisivos superiores e inferiores y deficiente higiene bucal con caries (Fig. 1). Se realizó una ortopantomografía y una telerradiografía lateral de cráneo que mostraron una anquilosis temporomandibular bilateral. Se completó el estudio con una TC con reconstrucción 3D (Fig. 2), toma de fotografías y valoración por el Servicio de Anestesiología. Las características sociales de la paciente impidieron indicar un tratamiento ortodóncico.

Se planificó la intervención quirúrgica contando con el consentimiento de su familia de acogida. La intubación nasotraqueal se efectuó con fibroscopio. Realizamos un abordaje preauricular con exposición del bloque anquilótico, el cual se resecó ampliamente creando una nueva cavidad glenoidea, sin interponer ningún material en el espacio creado. Se completó con una coronoidectomía con desinserción del músculo temporal bilateral. Seguidamente, tras comprobar una apertura oral de $30 \mathrm{~mm}$, colocamos un distractor extraoral de Molina fijado en el arco cigomático y en la rama mandibular ascendente, con la finalidad de elongar el tejido blan- together with a certain amount of shortening and hypertrophy of the masseter, pterygoid, temporal and suprahyoid muscles, due to isometric contractions. ${ }^{2}$

To date the best known treatment for ankylosis of the $T M J$ consists in resecting the ankylotic segment and fixing a costochondral graft with the aim of restoring facial height, making the deformity symmetrical and restoring oral opening. However, the growth potential of this graft is unpredictable, as intermaxillary fixation has to be carried out, and the donor site is not complication free. ${ }^{3}$

Over the last 15 years osteogenic distraction on a mandibular level has made a great contribution in the treatment of these patients, especially children.4 Technically, a resection of the ankylotic segment is performed together with and an osteotomy of the affected vertical branch; once the distraction vector has been checked, the distractor is placed and elongation is begun following a waiting period. In this way, mandibular symmetry is restored, occlusion is corrected and correct oral opening is achieved. $5,6,7,8$

In the case we present, we have used a distraction technique in order to elongate soft tissues and maintain the space between the glenoid cavity and the neck of the resected condyle so as to avoid collapse and re-ankylosis, and to stimulate in the process the formation of $a$ «neocondyle».

\section{Clinical Study}

We present the case of a nine-year-old girl from an African country that was sent to our Service through a charity. As a result of a fortuitous fall seven years previously, she had limited oral opening of $5 \mathrm{~mm}$ and a fracture in both condyles. On examination mandibular hypoplasia was observed with no symmetry, class II occlusion with compensation of upper and lower incisors, and deficient oral hygiene with caries (Fig. 1). An orthopantomography and a lateral teleradiography were made of the skull which showed bilateral temporomandibular ankylosis. The study was completed with a CT scan with 3D reconstruction (Fig. 2), photographs and evaluation by the Anaesthesiology Service. Orthodontic treatment was not possible due to the social background of the patient.

Surgical intervention was planned with the consent of her foster family. Nasotracheal intubation was carried out with a fiberscope. A preauricular approach was made exposing the ankylotic segment which was extensively resectioned and a new glenoid cavity was created. This was completed with a coronoidectomy with bilateral disinsertion of the temporal muscle. After confirming that there was an oral aperture of $30 \mathrm{~mm}$, we placed an extra-oral Molina distractor in the zygomatic arch and in the ascending mandibular branch, with the aim of elongating the soft tissue and preventing reankylosis. The superficial, bloody areas of the resection were kept separate. The same intervention was performed on the contralateral joint. (Fig. 3 and 4) 
do y prevenir la reanquilosis, manteniendo separadas las superficies cruentas de la resección. La misma intervención se realizó en la articulación contralateral (Figs. 3,4).

Tras un período de latencia de 5 días, iniciamos la distracción a $1 \mathrm{~mm}$ diario y la fisioterapia, la cual implicaba desactivar el distractor mientras se realizaban los ejercicios. La distracción se completó al conseguir una clase I. Durante el período de «consolidación» la paciente sufrió un accidente de tráfico que supuso el desanclaje del distractor derecho que se recolocó bajo anestesia general y mascarilla laríngea. La retirada definitiva de los distratores se llevó a cabo bajo anestesia local 11 semanas después de la cirugía. El seguimiento de la paciente fue mensual tras la retirada de los distractores, hasta que tuvo que regresar a su país a los 12 meses de la intervención, manteniendo la apertura oral de $30 \mathrm{~mm}$. (Fig. 5). No ha sido posible realizar un seguimiento a largo plazo.

\section{Discusión}

La alteración condilar producida en la infancia puede originar problemas estéticos y funcionales a nivel facial y articular, con repercusión en los tejidos blandos. De aquí se desprende que el tratamiento precoz de estos pacientes es beneficioso en tanto que minimiza las secuelas que se originan en el período de crecimiento. En 1990 Kaban ${ }^{9}$ presentó un protocolo de tratamiento de la anquilosis asociada a hipoplasia mandibular que consiste en resección del bloque anquilótico, coronoidectomía y desinserción muscular, interposición de fascia temporal o cartílago y reconstrucción con injerto costocondral. Este protocolo, ampliamente aplicado con modificaciones, presenta algunas desventajas, como la necesidad de bloqueo intermaxilar, morbilidad de la zona donante, eventuales transfusiones sanguíneas y crecimiento impredecible del injerto costocondral. Otras técnicas como las osteotomías mandibulares de deslizamiento sólo se pueden realizar cuando el período de crecimiento ha finalizado. En la última década, la aplicación de la distracción osteogénica en la región maxilofacial ha supuesto una revolución en el tratamiento de estos

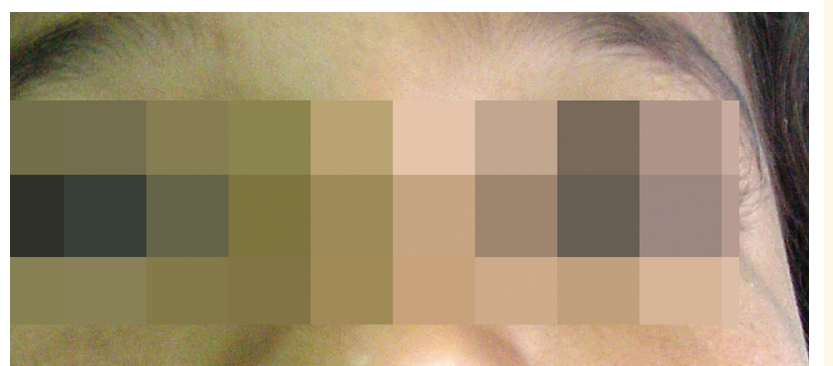

Following a five-day waiting period, we started distraction of $1 \mathrm{~mm}$ a day and physiotherapy, which implied deactivating the distractor while exercises were performed. Distraction was completed on reaching class 1 . During the "consolidation" period, the patient suffered a car accident which resulted in the right distractor becoming dislodged. This was put into place again with general anaesthetic and a laryngeal mask. The definitive removal of the distractors was carried out under local anaesthetic 11 weeks after surgery. There was a monthly follow-up of the patient following the removal of the distractors until she returned to her country 12 months after the intervention and maintaining an oral opening of $30 \mathrm{~mm}$. (Fig. 5). A longterm follow-up has not been possible.

Figure 1. Pre-op image showing limit of oral opening.

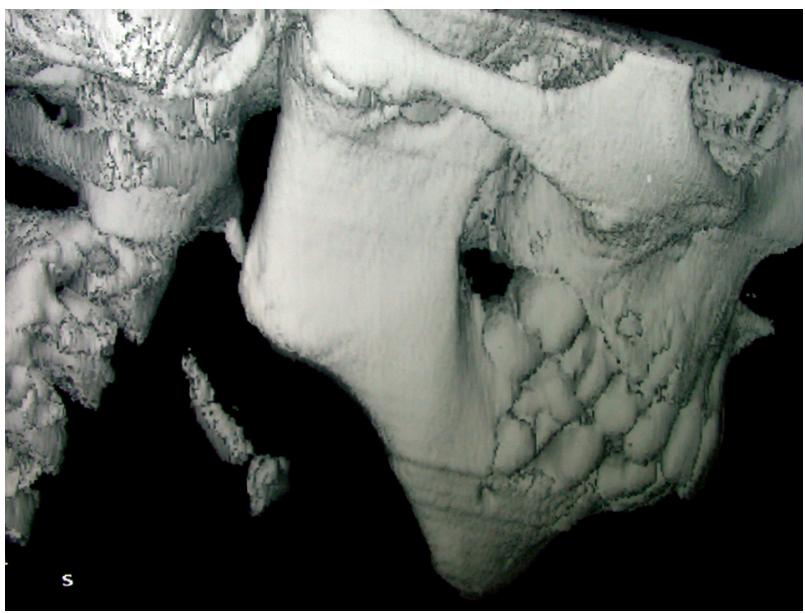

\section{Discussion}

Condylar changes produced during childhood can give rise to aesthetic and functional problems on a facial and speech level, with soft tissue repercussions. It is clear from this, that prompt treatment of ankylosis is beneficial, as the sequelae which originate during the growing stage, are minimized. In 1990 Kaban $^{9}$ presented a protocol for ankylosis management associated with mandibular hypoplasia which consisted in the resection of the ankylotic segment, coronoidectomy and muscular disinsertion, interposition of the temporal fascia or cartilage, and reconstruction with a costochondral graft. This protocol, applied widely with modifications, has some disadvantages such as the need for intermaxillary fixation, morbidity of the donor site, 
pacientes, puesto que permite su intervención en época de crecimiento, con la ventaja de minimizar las secuelas tardías, evitar el impacto psicológico en esta edad de escolarización e intentar reducir la morbilidad.

Se sabe que la deformidad del paciente anquilótico es el resultado de la falta de crecimiento de la epífisis condílea y la ausencia de estímulos de la matriz funcional de Moss. ${ }^{10}$ La distracción tiene un efecto beneficioso sobre el cóndilo, estimulándolo, aumentándolo de tamaño y reorientándolo más favorablemente. Además, según la teoría de la matriz funcional, si se elongan las inserciones neuromusculares se consigue estimular positivamente el crecimiento mandibular, y esta elongación gradual de los músculos, nervios, vasos y ligamentos mediante distracción es más beneficiosa que la elongación rápida que supone la colocación de un injerto, reduciéndose las posibilidades de recidiva. ${ }^{11-12-13}$

Por todo ello, en nuestro caso el empleo de la distracción fue encaminado hacia una elongación de los tejidos blandos, sobre todo los músculos masticadores, y como mantenedor de espacio entre el remanente condíleo tras la resección de la anquilosis y la nueva cavidad glenoidea, con el objetivo de evitar el contacto entre las superficies óseas que predispondría a la reanquilosis, es decir, se pretende en este caso liberar al «neocóndilo» de fuerzas compresivas para estimular su posterior desarrollo en una paciente en fase de crecimiento.

Por otro lado, hay controversia sobre si utilizar o no material de interposición para prevenir la reanquilosis. Se han empleado colgajos e injertos autólogos (músculo temporal, músculo masetero, fascia temporal, piel, cartílago), injertos heterólogos (por ejemplo, cartílago criopreservado de Banco de Tejidos), xenoinjertos (se ha descrito la utilización de cartílago bovino) y materiales aloplásticos (como silicona, acrílico y teflón). Nosotros no interpusimos ningún material, basándonos en algunos autores que consideran que si existen entre 1,5 y $3 \mathrm{~cm}$. entre la base de cráneo y la mandíbula y se instaura fisioterapia precoz no es necesario interponer ningún material ${ }^{14-15}$.

La fisoterapia precoz es esencial en estos pacientes. La ventaja que ofrece esta técnica respecto a las que requieren la utilización de un bloqueo intermaxilar es la posibilidad de iniciar los ejercicios de rehabilitación inmediatamente después de la cirugía.

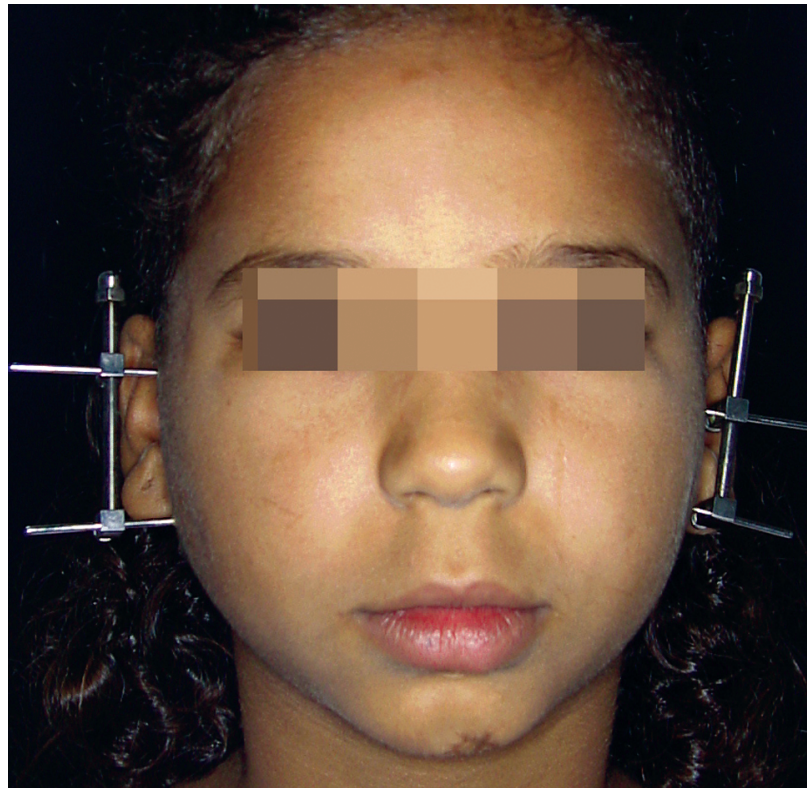

Figura 3. Imagen clínica postoperatoria de la paciente en fase de distracción.

Figure 3. Clinical post-op image of patient in distraction phase.

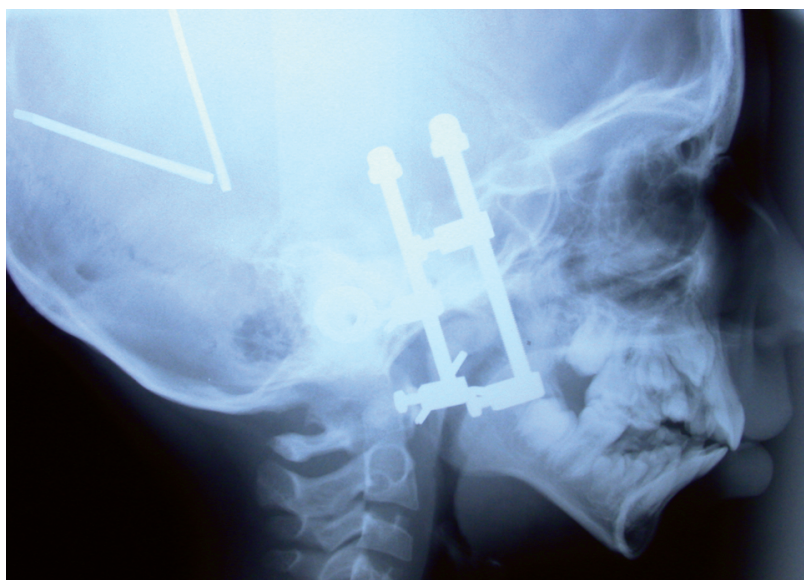

Figura 4. Rx lateral de cráneo mostrando lo distractores extraorales.

Figure 4. Lateral X -ray of cranium showing extra-oral distractors. possible blood transfusions and the unpredictable growth of the costochondral grafts. Other techniques such as sliding osteotomies of the mandible can only be performed once the growing period has finalized. Over the last decade, the application of distraction osteogenesis on the maxillofacial area has revolutionised the treatment of these patients, since it permits surgical intervention during the growth period. This has the advantage of minimizing later sequelae, it avoids psychological impact at a school age and an attempt is made to reduce morbidity.

It is known that deformity of the ankylotic patient is the result of the lack of growth of the condyle epiphysis and the lack of stimulation of the functional matrix according to Moss. ${ }^{10}$ Distraction has a beneficial effect on the condyle, stimulating it, increasing its size and redirecting it more favourably. In addition to this, according to the theory of the functional matrix, if the neuromuscular insertions are elongated, mandibular growth is achieved through positive stimulation, and this gradual elongation of the muscles, nerves, vessels and ligaments by means of distraction is of greater benefit than the rapid elongation which the placement of a graft implies, and the possibilities of a relapse are reduced. 11,12,13

Consequently, in our case, the use of distraction was designed to elongate soft tissues, especially the masticatory muscles, so as to maintain the space between the remaining condyle, following resection of the ankylosis, and the new glenoid cavity, with the aim of avoiding contact between bony surfaces which would lead to a predisposition for recurring ankylosis. In other words, the aim was in this case to release the "neocondyle» from the forces of compression, so as to stimulate later development in a growing patient.

On the other hand, there is controversy as to the use or 


\section{Conclusión}

En los casos de anquilosis con escasa deformidad, el uso de la distracción con la finalidad de elongar los tejidos blandos y mantener el espacio creado tras la artroplastia puede constituir una buena alternativa debido a su facilidad de ejecución y poca morbilidad.

\section{Agradecimientos}

A los Dres. F.J. Parri y M.A. Sancho de la Unidad Cráneo-Máxilo-Facial del Servicio de Cirugía Pediátrica del Hospital Sant Joan de Déu de Barcelona por su colaboración en este caso.

\section{Bibliografía}

1. Bradley P, James D, Norman JEB. Injuries of the Condylar and Coronoid Processes. Willians JLL (ed); Rowe and Willians`Maxillofacial Injuries. London: Churchill Livingstone 1994;P:405-473.

2. Dean A, Alamillos F. Mandibular distraction in temporomandibular joint ankylosis. Plast Reconstr Surg 1999;104:2021-2031.

3. Martín-Granizo R, Monje F, Fernández Sanromán J, Carreño A, Gil- Díez JL, Díaz FJ. Autoinjertos costocondrales en la reconstrucción del cóndilo mandibular. Rev Esp Cir Oral y Maxilofac 1997;19:189.

4. Acero J, Calderón J, Verdaguer F, Soler C, Concejo C. Distracción mandibular en un caso de hipoplasia mandibular neonatal asociado a anquilosis temporomandibular. Rev Esp Cir Oral y Maxilofac 1997;19:52.

5. McCarthy JG, Schreiber J, Karp N, Thorne CH, Grayson BH. Lengthening the human mandible by gradual distraction. Plast Reconstr Surg 1992;89:1-8.

6. Molina F, Ortiz Monasterio F. Mandibular elongation and remodeling by distraction: a farewell to major osteotomies. Plast Reconstr Surg 1995;96:825-840.

7. McCarthy JG, Stelnicki EJ, Mehrara B, Longaker MT. Distraction osteogenesis of the craniofacial skeleton. Plast Reconstr Surg 2001;107:1812-1827.

8. McCarthy JG, Katzen JT, Hopper R, Grayson BH. The first decade of mandibula distraction: Lessons we have learned. Plast Reconstr Surg 2002;110:1704-1713.

9. Kaban LB, Perrot DH, Fisher K. A protocol for management of temporomandibular joint ankylosis. J Oral Maxillofac Surg 1990;48:1145-1151.

10. Moss ML, Rankow RM. The role of the functional matrix in mandibular growth. Angle Orthod 1968;38:95-103

11. McCormick SU, McCarthy JG, Grayson BH, Staffenberg D, McCormick SA. Effect of mandibular distraction on the temporomandibular joint: I. Canine study. I Craniofac Surg 1995;6:358-363.

12. McCormick SU, Grayson BH, McCarthy JG, Staffenberg D. Effect of mandibular distraction on the temporomandibular joint: II. Clinical study. I Craniofac Surg 1995;6:364-367.

13. McCormick SU. Reconstruction of the mandibular condyle using transport distraction osteogenesis. J Craniofac Surg 1997;8:48-52.

14. Munro IR, Chen YR, Park BY. Simultaneous total correction of temporomandibular ankylosis and facial asymmetry. Plast Reconstr Surg 1986;77:517-527.

15. Topazian RG. Gap versus interposition arthroplasty for ankylosis of the temporomandibular joint. Oral Surg Oral Med Oral Pathol Oral Radiol Endod 2001;91:388. not of interposition material so as to prevent re-ankylosis. Flaps and autogenous tissue grafts have been used (temporal muscle, masseter muscle, temporal fascia, skin, cartilage), heterologous grafts (for example, cryopreserved cartilage from Tissue Banks), xenografts (the use of bovine cartilage has been described) and alloplastic material (silicone, acrylic and teflon). We did not interpose any material basing ourselves on the consideration of some authors that if there is between 1,5 and $3 \mathrm{~cm}$. between the base of the skull and the mandible, and if physiotherapy is begun quickly, there is no need to interpose any material. 14,15

Early physiotherapy is essential in these patients. The advantage that this technique offers, in comparison with those requiring intermaxillary fixation, is the possibility of starting rehabilitation exercises immediately after surgery.

\section{Conclusion}

In cases of ankylosis with little deformity the use of distraction with the aim of elongating soft tissue and maintaining the space created following arthroplasty, can constitute a good alternative due to the ease with which it can be performed and low morbidity. 